\title{
Constitutional Limitations to Long Arm Jurisdiction in Newspaper Libel Cases
}

Since the inception in 1945 of the "minimum contacts" test for determining the constitutional limits of state court power to assert personal jurisdiction over nonresident corporations, ${ }^{1}$ the barriers to the successful exercise of that jurisdiction have fallen rapidly; ${ }^{2}$ the introduction into a state of a single object can now be a sufficient basis for asserting jurisdiction if the injury occurs in the state and the plaintiff is a resident. ${ }^{3}$ When, however, such a low jurisdictional threshold is applied

1 International Shoe Co. v. Washington, 326 U.S. 310, 316 (1945): "Due process requires only that in order to subject a defendant to a judgment in personam, if he be not present within the territory of the forum, he have certain minimum contacts with it such that the maintenance of the suit does not offend 'traditional notions of fair play and substantial justice." "

Before 1945 the ability of the state to subject foreign corporations to the jurisdiction of its courts was quite restricted because it was thought that the due process clause required a showing that the corporation had "consented" to the state's exercise of jurisdiction by conducting in the state business which the state had the power to regulate. Washington ex rel. Bond \& Goodwin \& Tucker, Inc. v. Superior Ct., 289 U.S. 361 (1933); or that it was somehow "present" in the state because of the extent of its business activities there, International Harvester Co. v. Kentucky, 234 U.S. 579 (1914). See generally Kurland, The Supreme Court, The Due Process Clause and the In Personam Jurisdiction of State Courts, 25 U. CHI. L. REv. 569, 577-86 (1958).

2 See McGee v. International Life Ins. Co., 355 U.S. 220 (1957); Perkins v. Benguet Consolidated Mining Co., 342 U.S. 437 (1952); Travelers Health Association v. Virginia, 339 U.S. 643 (1950). See generally Kurland, supra note 1, at 593-610. But see Hanson v. Denckla, 375 U.S. 235, 251 (1958), where the Court indicated that there are still some constitutional barriers to the states' exercise of personal jurisdiction. International Shoe and subsequent Supreme Court decisions did not automatically eliminate the restrictions on the exercise of personal jurisdiction by the states, for the state legislatures still had to draft and pass statutes designed to take advantage of the extended limits, and the state courts had to determine whether the language used was adequate to accomplish this purpose. See Sonnier v. Time, Inc., I72 F. Supp. 576, 578 (W.D. La. 1959). But see St. Clair v. Righter, 250 F. Supp. 148, 152-54 (W.D. Va. 1966), where the court stated that the Constitution conferred on the state courts the "power" to assert jurisdiction to the constitutional limits even in the absence of a positive legislative sanction. For a discussion of the history and effect of the Illinois long arm statute, which has become a model for state legislatures in this area, see Currie, The Growth of the Long Arm, 1963 U. ILL. L.F. 533.

3 Elkart Eng'g Corp. v. Dornier Werke, 343 F.2d 861 (5th Cir. 1965) (action arising out of crash of plane being demonstrated in state by foreign company); Gray v. American Radiator \& Standard Sanitary Corp., 22 Ill. 2d 432, 176 N.E.2d 761 (1961) (defendant made defective safety valve in Ohio and sold it to independent dealer who attached the valve in Pennsylvania to a boiler which blew up in Illinois). See generally Currie, supra note 2. 
to newspapers in libel cases and personal jurisdiction over an out-ofstate newspaper is sought on the ground that the newspaper sent papers to a small number of subscribers within the state, the exercise of jurisdiction often appears to clash with other fundamental values. If jurisdiction is successfully asserted, the newspaper then faces not only the cost and inconvenience of defending a libel suit in a far-off jurisdiction, ${ }^{4}$ but also the prospect of a huge damage award handed out by a jury which may dislike the views expressed by the paper on controversial issues of local importance. ${ }^{5}$ In such circumstances it is quite possible that the newspaper will discontinue circulation of its editions within the state in order to avoid such litigation in the future. The state action thus threatens the unhampered circulation of newspapers and raises possible first amendment problems. ${ }^{\circ}$ Moreover, it might appear questionable to subject newspapers to what are likely to be unfair trials on the basis of such skimpy contacts; it seems appropriate, therefore, also to examine the due process aspects of the state's exercise of jurisdiction in an effort to determine whether the risks to which newspapers are exposed weigh more heavily than the plaintiffs' interests in having local forums in which to recover for injuries caused by newspapers. ${ }^{7}$

In New York Times Co. v. Connor ${ }^{8}$ the Fifth Circuit Court of Appeals, apparently moved by these constitutional arguments, attempted to grant newspapers a limited degree of protection from the reach of

4 The cost and inconvenience of trying the suit in a foreign jurisdiction are factors in determining whether a state can assert jurisdiction, McGee v. International Life Ins. Co., 355 U.S. 220, 223 (1957), but in the newspaper libel cases such a factor would seem to weigh in favor of the plaintiff since the important witnesses would probably reside in his state and since the inconvenience to him of trying the suit in the newspaper's home forum would probably be far greater than the inconvenience to the paper of trying the suit in the plaintiff's home forum. The newspapers, however, do not emphasize the additional cost of trying the suit because the trial will be held at some distance from their home state. Rather, they emphasize the likelihood that they will receive an unfair trial in the plaintiff's home forum. See Brief for the Chicago Tribune as Amicus Curiae, pp. 2-10, New York Times Co. v. Sullivan, 376 U.S. 254 (1964), discussing the "Star Chamber" tactics of trying newspapers in hostile forums. It is this aspect of the newspaper libel cases that will be emphasized in this comment.

5 See Mr. Justice Black's concurring opinion in New York Times Co. v. Sullivan, 376 U.S. 254, 294 (1964), indicating that libel trials can be used to punish unpopular newspapers. See also Berney, Libel and the First Amendment-A New Constitutional Privilege, 51 VA. L. Rev. 1, 55-56 (1965); cf. Chafee, Free SpeEch in the United States 60-79 (1948).

6 See Brief for Petitioner, pp. 89.90, Brief for The Washington Post as Amicus Curiae, p. 33, New York Times Co. v. Sullivan, 376 U.S. 254 (1964).

7 See Brief for The Chicago Tribune as Amicus Curiae, pp. 2-10, New York Times Co. v. Sullivan, 376 U.S. 254 (1964).

8365 F.2d 567 (5th Cir. 1966). 
the long arm statutes, and thereby breathed new life into the old and generally rejected high jurisdictional threshold for newspapers, ${ }^{9}$ by

9 The practice of minimizing the importance of circulation activities when deciding whether jurisdiction can be constitutionally asserted over a nonresident newspaper is not a new one. Before 1945, libel suits against newspapers were usually dismissed on the ground that the paper was not "doing business" within the state. See Street \& Smith Publications, Inc. v. Spikes, 120 F.2d 895 (5th Cir. 1941); Whitaker v. McFadden Publications, Inc., 105 F.2d 44 (D.C. Cir. 1939); cf. note 1 supra. Circulation and distribution activities alone were not considered sufficient to meet the requirements of the "doing business" test, at least where such activities were carried on by an independent distributor. Street \& Smith Publications v. Spikes, supra; Cannon v. Time, Inc., 115 F.2d 423 (4th Cir. 1940). After International Shoe Co. v. Washington, 326 U.S. 310 (1945), inaugurated the "contacts" test, such holdings have become more rare. Still, the "doing business" test, together with its corollary that circulation alone is not enough, does retain vitality in some courts, particularly in states where the state legislatures had not revised their long arm statutes at the time the case came up. See Walker v. Field Enterprises, Inc., 332 F.2d 632, 633 (10th Cir. 1964); Schmidt v. Esquire, Inc., 210 F.2d 908, 914-16 (7th Cir. 1954); Brewster v. Boston Herald-Traveler Corp., I41 F. Supp. 760, 763 (D. Me. 1956). Other courts have developed more sophisticated means for protecting newspapers. When the Connor case was before the Fifth Circuit for the first time, for example, the court relied on a combination of a meticulous reading of the wording of the Alabama long arm statute and a peculiar rule of libel law known as the single publication rule (which previously had been used mostly to limit the time within which an action might be brought and the number of places within the state where the action could be tried, see Age-Herald Publishing Co. v. Huddleston, 207 Ala. 40, 92 So. 193 (1921)), and held that under the applicable Alabama law "accrue" meant "to be completed," that a libel action does not "accrue" until the libelous article is published, and that new causes of action do not "accrue" after the first publication. New York Times Co. v. Connor, 291 F.2d 492 (5th Cir. 1961). See generally Comment, Newspaper Libel: Barriers to Expanding Personal Jurisdiction, 29 U. CHI. L. REv. 569, 572-77 (1962). The effect of this complicated logic was again to decrease the importance of circulation as a factor in deciding questions of jurisdiction.

In other cases decided after International Shoe, however, the newspapers have failed to escape the expansion of jurisdiction. In many states, for example, the legislatures have finally devised statutes which permit the exercise of jurisdictional powers to the constitutional limits; consequently, a careful reading of the statute will be of no help to the newspapers, since the courts will go directly to the Constitution in order to determine the permissible limits. See, e.g., Bibie v. T.D. Publishing Corp., 252 F. Supp. 185, 187 (N.D. Cal. 1966). In other jurisdictions the courts dismiss the technicalities of libel law and the mechanical aspects of the sales and printing arrangements made by the newspaper companies as too artificial to avoid the reach and obvious purpose of the jurisdiction statutes. Bibie v. T.D. Publishing Corp., supra, at 190; New York Times Co. v. Sullivan, 273 Ala. 656, 670, 144 So. 2d 25, 34 (1962), rev'd on other grounds, 376 U.S. 254 (1964); cf. Sonnier v. Time, Inc., 172 F. Supp. 576, 579 (W.D. La. 1959) (an action for false advertising). Finally, some courts include circulation and reporting with printing and advertising solicitation as essential aspects of a newspaper's business and hold that if any of these functions is carried on within a state, the paper has sufficient contacts with the state. Hunter v. Afro-American Co. of Baltimore City, 133 F. Supp. 812, 817 (E.D.S.C. 1955); cf. Consolidated Cosmetics v. D-A Publishing Co., 186 F.2d 906, 908 (7th Cir. 1951). Thus many courts, instead of granting special protection to newspaper circulation, have indicated that newspapers will be treated exactly as any other business for purposes of determining whether personal jurisdiction can be properly asserted by the 
holding that libel cases involving newspapers require a greater than normal showing of contacts. ${ }^{10}$ Shortly after the New York Times published an article on the civil rights agitation in Birmingham, Alabama, ${ }^{11}$ seven different libel suits with damage claims in excess of $\$ 3,000,000$ were filed against it in Alabama. ${ }^{12}$ Service under the Alabama long arm statute $^{13}$ was based on an average circulation within the state of 395 copies of the daily edition of the Times and 2,455 copies of the Sunday edition, the temporary presence in Alabama of the staff reporter who wrote the article, the purchase of a number of news stories, and the solicitation of a slight amount of advertising during the preceding year. ${ }^{14}$ After a series of appeals in which the service of process was validated, ${ }^{15}$ the case went to trial, and the jury returned a verdict in favor of Connor for $\$ 40,000$ in general damages. ${ }^{16}$

state courts. See also Roy v. North American Newspaper Alliance, Inc., 106 N.H. 92, 205 A.2d 844 (1964).

10365 F.2d at 572.

11 N.Y. Times, April 12, 1960, p. 1, col. 1.

12 The total punitive and general damages alleged was $\$ 3,100,000$. N.Y. Times, May 17 , 1961, p. 22, col. 3 .

13 Ala. Acts 1953, \& 1, at 347 (now AlA. Code tit. 7, § 199(1) (Supp. 1965): "Any ... corporation not qualified under the Constitution and laws of this state as to doing business herein, who shall do any business or perform any character of work or service in this state shall, by the doing of such business or the performing of such work, or services, be deemed to have appointed the secretary of state, or his successor or successors in office, to be the true and lawful attorney or agent of such non-resident, upon whom process may be served in any action accrued or accruing from the doing of such business, or the performing of such work, or service, or as an incident thereto by any such non-resident, or his, its or their agent, servant or employee . . . ."

The statute, as amended in 1961, allows service on the secretary "in any action accrued, accruing, or resulting from the doing of such business ... or relating to or as an incident thereof .... And such service shall be valid whether or not the acts done in Alabama shall of and within themselves constitute a complete cause of action." AlA. CoDE tit. 7, § 199(1) (Supp. 1965). (Emphasis added.)

$14365 \mathrm{~F} .2 \mathrm{~d}$ at 570 . The circulation in Alabama accounted for $0.06 \%$ of the total circulation of the daily edition of the Times and $0.19 \%$ of the Sunday edition. Advertising solicitors visited Alabama 5 times between April 1959 and August 1960. The advertising revenue from Alabama amounted to between $0.025 \%$ and $0.046 \%$ of the total advertising revenue for the Times during the periods involved. The Times paid a total of $\$ 415$ for the stories it bought from the independent newsmen.

15 On the first appeal the Fifth Circuit held that the Alabama statute did not permit the exercise of jurisdiction over the Times because the initial cause of action had arisen outside of the state. New York Times Co. v. Connor, 291 F.2d 492, 495 (5th Cir. 1961). In the second appeal a clarification by the Alabama Supreme Court of Alabama libel law and of the reach of the Alabama long arm statute, New York Times Co. v. Sullivan, 273 Ala. 656, 670, 144 So. 2d 25, 34 (1962), rev'd on other grounds, 376 U.S. 254 (1964), forced the circuit court to reverse itself and to allow the trial to continue, Connor v. New York Times Co., 310 F.2d 133 (5th Cir. 1962), though it reserved judgment on possible constitutional limitations to the exercise of jurisdiction, $i d$. at 135.

16 New York Times Co. v. Connor, 365 F.2d 567, 569 (5th Cir. 1966). 
The Fifth Gircuit reversed on two grounds: first, that the district court lacked jurisdiction over the Times: ${ }^{17}$ and, second, that there was not enough evidence to support the finding of "actual malice" required by the Supreme Court's holding in New York Times Co. $v$. Sullivan. ${ }^{18}$ In making its jurisdictional finding, the court announced that:

First Amendment considerations surrounding the law of libel require a greater showing of contact to satisfy the due process clause than is necessary in asserting jurisdiction over other types of tortious activity. ${ }^{19}$

An examination of "first amendment considerations," however, indicates that not only do they not compel a higher jurisdictional threshold, but their incorporation into a long arm formula would produce several undesirable consequences.

The Supreme Court has long recognized that whenever the flow of information to the public is curtailed or the presentation of conflicting viewpoints hampered, the democratic process functions less effectively, for individuals in a democracy must have readily available pertinent factual information and explanations of conflicting policy positions in order to evaluate intelligently the decisions made by their agents in government. ${ }^{20}$ Consequently, the Court has sought to encourage the circulation of newspapers, religious pamphlets, and political circulars by bringing the distribution of such materials under the protective umbrella of the first amendment. ${ }^{21}$ Thus, when government action is aimed directly at curtailing the circulation of a newspaper, the Court has had no difficulty in finding a violation of the first amend-

17 Id. at 571 .

$18 \mathrm{Id}$. at 577 .

$19 \mathrm{Id}$. at 572.

20 See Whitney v. California, 274 U.S. 357, 375 (1927) (Brandeis, J., concurring): "Those who won our independence believed ... that freedom to think as you will and to speak as you think are means indispensable to the discovery and spread of political truth; that without free speech and assembly discussion would be futile; that with them, discussion affords ordinarily adequate protection against the dissemination of noxious doctrine; that the greatest menace to freedom is an inert people; that public discussion is a political duty; and that this should be a fundamental principle of the American government." See generally ChafeE, Free SPEEch IN tHe United STATES 16-22 (1948); MeikzEJohn, Polttical Freedom 8-28 (1960); Emerson, Toward a General Theory of the First Amendment, 72 YALE L.J. 877, 882-86 (1963).

21 Talley v. California, 362 U.S. 60 (1960) (political pamphlets); Martin v. Struthers, 319 U.S. 141 (1943) (religious material); Schneider v. New Jersey, 308 U.S. 147 (1939) (political pamphlets and religious material); Hague v. CIO, 307 U.S. 496 (1939) (political pamphlets); Grosjean v. American Press Co., 297 U.S. 233 (1936) (newspaper); Near v. Minnesota, 283 U.S. 697 (1931) (newspaper). 
ment. ${ }^{22}$ Even where government activity affects circulation only indirectly, the Court has generally found that such activity violates first amendment guarantees if it tends to impede circulation. ${ }^{23}$ There are, of course, limits to the protection the Court will grant to circulation activities. With respect to commercial advertisements, the Court will usually defer to legislative judgments. ${ }^{24}$ Occasionally, other countervailing considerations compel the Court to approve activity which has the effect of restricting the circulation of pamphlets and opinions. ${ }^{25}$ Thus, the Court has held that the amendment does not cloak the author of a libelous article with immunity from libel suits once the

22 See, e.g., Near v. Minnesota, 283 U.S. 697 (1931), where the Court held that a statute which permitted the state courts to enjoin permanently the publication of any newspaper found to be "malicious, scandalous and defamatory" imposed on newspapers the kind of prior restraint forbidden by the Constitution, even though the newspaper involved was a "scandal sheet" and truth published with good motives would have been a good defense. Id. at 701-02, 724 n.l. See also Grosjean v. American Press Co., 297 U.S. 233 (1936).

23 See, e.g., Martin v. Struthers, 319 U.S. 141 (1943); Schneider v. New Jersey, 308 U.S. 147 (1939). In Schneider, where the Court had to rule on the constitutionality of four ordinances which regulated the distribution of political and religious pamphlets, the cities urged that the three ordinances restricting pamphlet distribution to certain designated places were designed not to curtail circulation but to keep the streets clean, and that the fourth ordinance, which required those who wanted to solicit funds or distribute circulars door to door to first obtain a permit from the chief of police, was passed to protect citizens from bothersome and possibly fraudulent appeals for funds. 308 U.S. at 159, 162. Although the court recognized that keeping the streets clean and protecting citizens from fraud were legitimate functions of a city government, it nevertheless held that since the ordinances did inhibit circulation and since there were other means available for protecting the public from the evils which the ordinances sought to remedy, the ordinances violated the first amendment rights of the pamphlet distributors. Id. at 160, 162-64.

24 Breard v. Alexandria, 341 U.S. 622, 637-38 (1951). See also Valentine v. Chrestenson, 316 U.S. 52, 54 (1942), where the Court, in holding that attaching a political protest to a commercial pamphlet did not change the commercial nature of the pamphlet, stated: "We are equally clear that the Constitution imposes no such restraint on government as respects purely commercial advertising. Whether, and to what extent, one may promote or pursue a gainful occupation in the streets, and to what extent such activity shall be adjudged a derogation of the public right of the user, are matters for legislative judgment."

25 If there are no alternative means for dealing with a particular problem the Court might allow the city officials to restrict speech and circulation activities. Compare Kovacs v. Cooper, 336 U.S. 77 (1949), where there was virtually no other way of protecting those inconvenienced by noisy sound trucks except to permit the city to ban trucks which emitted "loud and raucous" noises, with Martin v. Struthers, 319 U.S. 141, 147-48 (1943), and Schneider v. New Jersey, 308 U.S. 147, 162 (1939). Another factor that may influence the Court's decision is the character of those who circulate. Compare Martin v. Struthers, 319 U.S. 141, 146 (1943), suggesting that circulation methods available to poor people as well as rich need more protection than those means available only to rich people, with Prince v. Massachusetts, 321 U.S. 158 (1944), involving the regulation of the distribution of religious literature by children under the child labor laws. See generally Niemotko v. Maryland, 340 U.S. 268, 276-83 (1951) (Frankfurter, J., concurring). 
article has been published, even though the threat of a libel suit might deter him from circulating his defamatory material, for the need to protect the reputation of maligned individuals and to control the dissemination of falsehoods outweighs whatever limitations might be placed on circulation by the libel laws. ${ }^{26}$

The newspapers urge, however, that because of the particularly heavy burden placed upon them when a minimum contacts test is applied in libel cases, the interests in favor of unrestrained circulation should entitle them to special protection from the reach of the long arm statutes. The newspapers note that in libel cases arising out of the reporting of highly controversial issues and events, the chances of losing and being forced to pay substantial damage awards are great, not only because the facts are unlikely to be clear and certain in such heated situations, but also and more importantly because the vaguely defined elements of libel law enable judges to manipulate the law to the disadvantage of a newspaper defendant and juries to make findings of fact against the newspaper solely because its reporting incensed the local population. ${ }^{27}$ Consequently, if jurisdiction can be based on the

26 Beauharnais v. Illinois, 343 U.S. 250, 254-57 (1952); Chaplinsky v. New Hampshire, 315 U.S. 568, 571-72 (1942); Near v. Minnesota, 283 U.S. 697, 715 (1931). This restriction on the scope of the first amendment is, however, diminishing in strength because of the impact of New York Times Co. v. Sullivan, 376 U.S. 254 (1964).

27 See Berney, Libel and the First Amendment-A New Constitutional Privilege, 51 VA. L. Rev. 1, 55-56 (1966); cf. Chafee, Free Speech in the United States 60-79 (1948). The jury is responsible for determining such difficult matters of fact as truth and intent. Even if the jury were not consciously trying to be unfair to the newspaper, in its eyes all unpopular ideas might seem like outright lies which could not possibly have been published without knowing that they were untrue. See Berney, supra, at 55-56; cf. United States v. Ballard, 322 U.S. 78, $92-93$ (1944). The trial judge can control the jury to some extent by deciding whether a particular article is libelous per se and therefore whether general damages can be presumed without further proof of actual injury, see New York Times Co. v. Sullivan, 273 Ala. 656, 673, 144 So. 2d 25, 37 (1962), rev'd on other grounds, 376 U.S. 254 (1964), or by reviewing the damage award, see Flanigan v. Carswell, 324 S.W.2d 835, 839 (Tex. 1959). But he is not forced to exercise his control in any of these instances, Coats v. The News Corp., 355 Mo. 778, 784-85, 197 S.W.2d 958, 962 (1946), and the more he dislikes the paper the less likely he is to exercise his discretion objectively. See Berney, supra, at 55-56; CHAFFEE, op. cit. supra, at 60-79.

The virtually unchecked power of the jury to determine the size of the damage award constitutes an especially great threat to newspapers in these libel cases. If the publication is libelous per se, damages are conclusively presumed, and the plaintiff need not introduce any evidence tending to show actual loss of reputation, pecuniary damages, hurt feelings, or the like; the jury simply sets a figure which it feels would be "fair." Keller v. Safeway Stores, Inc., 111 Mont. 28, 108 P.2d 605 (1940). See generally Grecory \& Kalven, Cases on Torts 919-26 (1959); Prosser, Torts § 107, at 780-82 (3d ed. 1964). The jury can also award substantial punitive damages on a showing of malice, Reynolds v. Pegler, 123 F. Supp. 36, 38-39 (S.D.N.Y. 1954) (\$3.00 general damages and a total of $\$ 175,000$ punitive damages awarded against 3 defendants), as well as compensate the 
circulation of relatively few newspapers in a particular state, the newspapers claim that they will have no choice but to discontinue their circulation, since the economic benefits received from the sale of the papers in the state would not compensate for the risk of having to try a libel suit in the distant and probably hostile forum. ${ }^{28}$

Although there has been no indication that any newspaper has reduced its circulation in order to avoid the long arm statutes-the New York Times, for instance, has not cut off any of its subscribers in the southern states despite the many libel suits brought there against it in recent years as a result of its civil rights reporting ${ }^{29}$ - this economic argument still has considerable force. The Times cannot continue to endure $\$ 40,000^{30}$ and $\$ 500,000^{31}$ libel verdicts whenever its reporters become highly critical of certain southerners, and if it were convinced that it could avoid such verdicts only if it stopped sending papers into Alabama or stopped criticizing the racial situation in the South, it might seriously consider eliminating its southern circulation. Since the need for information is so great and since the Supreme Court has never insisted that there be an actual cessation of protected activity before an unconstitutional encroachment on first amendment freedoms will be found, ${ }^{32}$ the extra burden placed on newspaper circulation in fringe areas of distribution because of the threat of a libel suit may seem to constitute an infringement of first amendment rights, in spite of the interests that favor protecting the libeled individual.

Today, when a town served by more than one newspaper is becoming a rarity, ${ }^{33}$ the usual arguments for unhampered interstate news-

plaintiff for special damages if pleaded and supported by specific proof, Ellsworth $v$. Martindale-Hubbell Law Directory, Inc., 68 N.D. 425, 280 N.W. 879 (1938). See generally Gregory \& Kalven, Cases on TORTS 913-19 (1959). Since objective means for measuring damage to one's reputation are virtually nonexistent, the jury has great freedom to set any figure it likes in assessing the extent to which the plaintiff was harmed. Awards for general damage vary from 6 cents, Ford v. Chicago Tribune, No. 67999, Cir. Ct. Wayne County, Mich., Sept. 24, 1907, to $\$ 2,000,000$, Faulk v. Aware, Inc., 35 Misc. 2d 302, 231 N.Y.S.2d 270 (1962). See generally Annot., 35 A.L.R.2d 218 (1954).

28 See Brief for Petitioner, pp. 88-89, Brief for The Washington Post as Amicus Curiae, p. 33, New York Times Co. v. Sullivan, 376 U.S. 254 (1964).

29 See Pedrick, Freedom of the Press and the Law of Libel: The Modern Revised Translation, 49 CoRNeLL L.Q. 581, 582 n.2 (1964).

30 Connor v. New York Times Co., 365 F.2d 567 (5th Cir. 1966).

31 New York Times Co. v. Sullivan, 376 U.S. 254 (1964).

32 See Talley v. California, 362 U.S. 60, 64 (1960); Thomas v. Collins, 323 U.S. 516, 539-40, 543 (1945). See also Poulos v. New Hampshire, 345 U.S. 395, 424 (1953) (Black, J., dissenting).

33 In 1960 the number of cities with daily newspapers was 1461, but of these only 61 had competing dailies. By 1962 the number of cities with competing dailies had dropped to 55. IntERnational Typographical Union, Federal Responsibility For a FreE aND Competrtive Press 43 (1963). 
paper circulation are strengthened, since the possibility of obtaining an out-of-state newspaper might reduce the harmful effects of a local newspaper monopoly. An out-of-state newspaper, for example, can assume the task of revealing corruption or other civic shortcomings if the local paper refuses to dig into an issue which might incense its publisher or the local citizens. ${ }^{34}$ Also, local readers can turn to an outof-state paper if monopolization of the communications media in a particular community leads to slanted reporting of the news. ${ }^{35}$ Clearly, then, it is undesirable to cut off one of the few sources through which unpopular ideas can be presented to the community. Thus, if the first amendment freedoms threatened were the only determining factor in defining the scope of the first amendment protections, the need to encourage interstate newspaper circulation coupled with the general interests favoring circulation would seem to indicate that the burden placed on circulation by the imposition of a minimum contacts test is sufficient to justify the result in the Connor case.

This limited interest analysis, however, does not resolve the question, for the goals sought to be accomplished by the long arm statutes, the alternative means of dealing with the libel problem, and, in general, the propriety and effectiveness of restricting governmental action at the jurisdictional level on first amendment grounds must also be considered. ${ }^{36}$ No Supreme Court decision has yet extended the boundaries of the first amendment into the area of jurisdiction. Moreover, as will be seen, the policies and rationale underlying previous extensions

34 Thayer, Legal Control of the Press 217-18 (4th ed. 1962); Berney, supra note 27, at $33,35-36$.

35 InTERnATIONAL TXPOGRAPhical UNion, op. cit. supra note 33, at 99-108.

36 The first amendment does not prohibit all governmental activity which restricts the exercise of first amendment freedoms. Thus, newspapers must pay nondiscriminatory taxes, Grosjean v. American Press Co., 297 U.S. 233, 250 (1936) (dictum), and they are subject to the regulatory power of the National Labor Relations Board, Associated Press v. NLRB, 301 U.S. 103, 132-33 (1937). The government can, for example, channel and regulate first amendment activities by establishing hours when pamphlets can be distributed. Schneider v. New Jersey, 308 U.S. 147, 165 (1939) (dictum).

In these cases the inhibiting government action fell equally on all those affected. When, however, government action discriminates against a group's exercise of first amendment freedoms, the action will not be permitted. See Niemotko v. Maryland, 340 U.S. 268 (1951); Grosjean v. American Press Co., supra. Where it is not clear whether the government activity is discriminatory, it is often helpful, in order to decide whether the government action is permissible, to concentrate the analysis on the nature of the government activity rather than on the particular rights affected and the degree to which they are hindered. Such an examination will focus attention on the problems sought to be corrected by the government action and the possibilities of dealing with the problem in other ways, whereas a more limited interest analysis might tend to ignore these factors. See generally Frantz, Is the First Amendment Law?-A Reply to Professor Mendelson, 51 CAL.TF. L. Rev. 729, 736-37 (1963). 
of the scope of the first amendment are not applicable to problems encountered at the jurisdictional level; indeed, application of first amendment doctrines at the jurisdictional level both fails to protect some activities which should fall within the scope of the first amendment and grants unwarranted protection to other activities.

In attempting to support its first amendment proposition, the Connor court argued that the problem in the newspaper libel cases resembled the situation in certain cases in which the Supreme Court has used first amendment doctrines to strike down vague laws which might be used by public officials to hamper and discourage those who support unpopular doctrines. ${ }^{37}$ Certainly, the Court has recognized that because some broadly drafted laws and ordinances are peculiarly susceptible to uses which unfairly discriminate against certain individuals and groups, the mere existence of such laws constitutes a threat to first amendment freedoms. Consequently, it has insisted that statutes which are likely to affect the exercise of first amendment freedoms be carefully drawn in order to insure both that they will not be misused by state prosecutors and that persons exercising first amendment rights will know what activity the statute covers. ${ }^{38}$ In many respects the burden on circulation in the newspaper libel cases stems from uncertain law, for, as indicated earlier, the newspapers fear that the judge and jury might use the discretion granted them by the libel laws to discriminate against the newspapers. ${ }^{39}$ This argument, however, is not applicable at the level where jurisdictional questions are decided, for at this level the discretionary leeway of the state officials, judges in this instance, is limited to deciding how much weight will be given to the various business contacts that the newspaper has with the state, ${ }^{40}$ and even this

37365 F.2d at 573 (1966), where the court cites NAACP v. Button, 371 U.S. 415 (1963). A similar argument was suggested by the dissenter in Connor, who stated that where there was no causal connection between the corporation's contacts with the state and the cause of action, the application of a long arm statute to newspapers might be equated with illegal attempts by a city to forbid the distribution of literature without first obtaining written permission. 365 F.2d at 582 (1966) (Lynne, J., dissenting); see Staub v. City of Baxley, 355 U.S. 313 (1958); Schneider v. New Jersey, 308 U.S. 147 (1939); Hague v. CIO, 307 U.S. 496 (1939). Since the opportunity to discriminate at the level of jurisdiction is extremely limited in both cases, both arguments are subject to the same weaknesses.

38 See, e.g., Edwards v. South Carolina, 372 U.S. 229 (1963); NAACP v. Button, 371 U.S. 415, 432-35 (1963); Staub v. City of Baxley, 355 U.S. 313, 325 (1958); Kunz v. New York, 340 U.S. 290 (1951); Niemotko v. Maryland, 340 U.S. 268 (1951); Thomas v. Collins, 323 U.S. 516, 535 (1945); Schneider v. New Jersey, 308 U.S. 147, 163 (1939); Lovell v. City of Griffin, 303 U.S. 444, 450-51 (1938).

30 See note 27 supra and accompanying text.

40 International Shoe Co. v. Washington, 326 U.S. 310, 320 (1945). Numerous articles, comments, and legal opinions have been written about the kinds of contacts which 
limited exercise of discretion is subject to the review of the appellate courts. The newspapers' problems, in other words, are not related to uncertainty in applying the long arm statutes and the abuses which this uncertainty might encourage. Thus, the first amendment precedents involving broadly drafted statutes are not particularly analogous.

Cases in which the Court has sought to impose limitations on the jury's exercise of discretion in order to decrease the chances that the jury might find that privileged speech was in the unprotected category $^{41}$ are perhaps more directly relevant to the newspaper libel situation, since abuses arising from the jury's exercise of discretion are the principal evil against which the newspapers have reacted. In the speech cases, however, the Court has traditionally sought to correct the problem at the level at which it arose. Thus, in New York Times Co. $v$. Sullivan ${ }^{42}$ the Court held that when a libel involves a public official acting in his official capacity, the plaintiff must show at the trial that the allegedly libelous statements were printed with the knowledge that they were untrue or with recklessness as to their falsity before he is entitled to a damage award. ${ }^{43}$ In Speiser $v$. Randall ${ }^{44}$ the Court indicated that by placing the burden of proving loyalty in order to qualify for a tax exemption on the individual claiming the exemption, the state had increased the risk of penalizing legitimate speech since such a procedure broadens the area within which a jury might find that the speech of an applicant-possibly legitimate speech given the inherent danger of erroneous fact-finding-might be a basis for a finding of disloyalty. ${ }^{45}$ In order to insulate legitimate speech as much as possible, the Court insisted that the burden be on the state.48

As in Speiser and Sullivan, the central problem in the newspaper libel cases involves uncertainty as to how the judge and jury might act during the trial. But the method proposed by the Connor court to alleviate this problem-engrafting first amendment considerations onto

must be shown before a court can exercise jurisdiction over a foreign corporation. For a court opinion discussing some of the relevant considerations see Bibie v. T.D. Publishing Corp., 252 F. Supp. 185, 189-90 (N.D. Cal. 1966). Two of the leading articles are Currie, Growth of the Long Arm, 1963 U. ILL. L.F. 533, and Kurland, The Supreme Court, The Due Process Clause and the In Personam Jurisdiction of State Courts, $25 \mathrm{U}$. CHI. L. REv. 569 (1958).

41 See New York Times Co. v. Sullivan, 376 U.S. 254 (1964); Speiser v. Randall, 357 U.S. 513 (1958); cf. Smith v. California, 361 U.S. 147, 153 (1959).

42376 U.S. 254 (1964).

$43 I d$. at $279-80$.

44357 U.S. 513 (1958).

45 Id. at 525-26.

$46 I d$. at 529 . 
the "contacts" test for determining jurisdiction"7_-does nothing to diminish the uncertainty at the trial court level. Moreover, the principle of the Connor case not only fails to confront directly the central problems in the libel cases, but its application could result in two undesirable consequences. Since the protection afforded by the Connor doctrine would be limited to newspapers with interstate circulation, in-state newspapers, including those with views inimical to the local population, would be left unprotected; such a result contrasts sharply with the traditional free speech case in which all those likely to be affected by the particular uncertainty involved are equally protected. ${ }^{48}$ Furthermore, the Connor proposition would grant protection to activities which are not otherwise privileged under the first amendment. Intentional libels, for example, would receive protection, even though the Sullivan case indicated that the first amendment should not be so extended. ${ }^{49} \mathrm{It}$ is highly questionable whether the first amendment requires all libeled plaintiffs from jurisdictions where a newspaper's circulation is small to sue in the newspaper's home forum, regardless of the kind of libel or the kind of plaintiff involved, when such a requirement might easily involve considerable expense and inconvenience for both the plaintiff and witnesses who had to be brought from the plaintiff's jurisdiction and which might bring the plaintiff before a jury prejudiced in favor of the defendant. Thus, the Connor doctrine, by concentrating solely on the affected first amendment freedoms, ignores considerations which normally would call for trial of the suit in the plaintiff's home forum..$^{50}$

The Connor decision also offers some support for the proposition that a proper application of the "contacts" test, apart from any dependence on the first amendment, requires the court to treat newspapers somewhat differently from other kinds of businesses. Thus, the court spoke of "first amendment considerations" 11 rather than of legal principles derived from its analysis of the first amendment cases. Moreover, the case on which the Connor court relied most heavily for its narrow holding on the facts, Buckley $v$. New York Times Co., ${ }^{52}$ was decided

47365 F.2d at 572.

48 See text accompanying notes $42-46$ supra.

49376 U.S. at 281-83.

50 Such factors as expense to the plaintiff (especially individual plaintiffs with small money claims), availability of witnesses, and the interest of the state in the litigation have usually been given considerable weight by the courts when applying the contacts test. See McGee v. International Life Ins. Co., 355 U.S. 220, 223-24 (1957); Travelers Health Assn. v. Virginia, 339 U.S. 643, 648-49 (1950); Bibie v. T.D. Publishing Corp., 252 F. Supp. 185, 189 (N.D. Cal. 1966); Currie, supra note 40, at 577.

61365 F.2d at 572.

62338 F.2d 470 (1964). 
solely on due process grounds. ${ }^{53}$ Thus, the Connor proposition can be seen as an attempt to incorporate into the "contacts" test only the policies underlying the first amendment cases without relying directly on first amendment theories. Since the argument was not developed in Connor, it should be expanded before being subjected to critical analysis. As will be seen, however, the due process clause does not require a more-than-minimum contacts standard for newspapers any more than does the first amendment.

The due process argument can be advanced along two lines. First, the policies underlying the first amendment doctrines presented in the preceding section can be given weight in the jurisdictional balancing formula. The courts would, after all, like to encourage newspaper circulation $^{54}$ and to control unfair libel trials, ${ }^{55}$ and granting out-ofstate newspapers a limited degree of immunity from litigation is one way of accomplishing these results. Indeed, it is already the announced policy in New York, by statute, ${ }^{56}$ and in Mississippi, by judicial decision, $^{57}$ to limit the application of the long arm statutes in libel cases. ${ }^{58}$ Although the adoption of a particular policy by a number of jurisdictions does not turn that policy into a due process requirement, the vagueness of the due process test that the assertion of jurisdiction be in accord with "traditional notions of fair play," 59 as opposed to the imperatives of the first amendment, ${ }^{60}$ invites a court that wants to protect foreign newspapers to incorporate such apparently widely held views into the "contacts" formula. ${ }^{61}$

The second aspect of the due process argument involves the dependence of modern day newspapers on advertising for most of their in-

53 Id. at $474-75$.

54 See text accompanying notes 20-23 supra.

55 See New York Times Co. v. Sullivan, 376 U.S. 254, 294 (1964) (Black, J., concurring). 56 N.Y. Crv. PrAc. AGT §§ 302(a)(2)-(3) (Supp. 1966).

57 Walker v. Savell, 335 F.2d 536, 544 (1964): "It may well be the policy of the state of Mississippi to require a much stricter showing of the doing of business within that state by a foreign newspaper . . . before it is to be held amenable to local service in a libel suit than would be the case in a suit against an ordinary commercial corporation. We think there is reason for such a distinction because of the inherent danger or threat to the free exercise of the right of freedom of the press if jurisdiction in every state can be inferred from minimal contacts."

58 The reluctance of some courts to apply their enhanced jurisdictional powers to newspapers in libel suits is another indication that the idea that the application of a minimum contacts test to newspapers threatens fundamental values has been accepted in some quarters. See note 10 supra.

59 International Shoe Co. v. Washington, 326 U.S. 310, 316 (1945).

60 "Congress shall make no law ... abridging the freedom of speech or of the press . . ." U.S. Const. amend. I.

61 Meiklejohn, Political Freedom 36-37 (1960). 
come. Seventy-one per cent of their total revenue comes from advertising ${ }^{62}$ and sixty per cent or more of the content of their daily editions is devoted to advertising. ${ }^{63}$ Since one of the major motivating forces behind the expansion of jurisdiction has been the need to provide the states with some means for coping with the increasing amount of interstate business activity, ${ }^{64}$ it can be argued that the major profit-making activities of a corporation-advertising activities in the case of newspapers-should be given considerably more weight than other contacts the business might have with the state. ${ }^{65}$ Thus, in jurisdictions where the number of a newspaper's subscribers is small, circulation activities would be given practically no weight since they would normally add little to a newpaper's advertising income. ${ }^{66} \mathrm{~A}$ combination of this deemphasis on circulation with the general policy considerations for protecting newspaper circulation might seem to compel the courts on due process grounds to require more contacts than the circulation of a few newspapers before they will assert personal jurisdiction over a foreign newspaper corporation in a libel case.

Both prongs of this due process argument, however, misapply the "contacts" test, for they concentrate on the kind of business involved in the action rather than on the kind and quantity of the business' contacts with the states and by so doing undermine the "fairness" standard for which the "contacts" test has come to stand. ${ }^{67}$ It is possible

62 International TYPOGRAPHical Union, op. cit. supra note 33, at 27.

63 Id. at 28.

64 Hanson v. Denkla, 357 U.S. 235, 251 (1958); McGee v. International Life Ins. Co., 355 U.S. 220, 222-23 (1957).

65 This proposition can be connected to the "contacts" doctrine by arguing that minor circulation contacts are not of such a "quality and nature," International Shoe Co. v. Washington, 326 U.S. 310,319 (1945), that they would justify the state's exercise of jurisdiction. See Brief for The Washington Post as Amicus Curiae, p. 31, New York Times Co. v. Sullivan, 376 U.S. 254 (1964).

66 Subscriptions and circulation do affect advertising revenue since their size is a factor in determining the amount that a newspaper will be able to charge for running an advertisement, but the number of subscribers in areas where the newspaper's circulation is sparse would normally be a negligible factor in determining the rate schedules since most advertisers, particularly the local ones, would be aiming at readers within the primary area of circulation. See InTERnational Typographical Union, op. cit. supra note 33 , at 159 .

67 It is difficult adequately to define what fairness and unfairness mean for constitutional purposes in the jurisdictional context. Professor Currie gives as good an explanation as any: "Probably the most that can be said in a general way is that due process embodies a test of fundamental fairness in all steps of the proceedings; that our sense of fairness is outraged by certain assertions of jurisdiction on the part of States unconnected with the parties or with the controversy; and that this sense of unfairness stems partly from the inconvenience and expense involved, partly from the idea of unfair surprise, partly from anticipation of an improper choice of law, and partly from more 
for a legislature ${ }^{68}$ or even a court, ${ }^{69}$ on nonconstitutional grounds, to give newspapers preferential treatment under the long arm statutes; the only consideration for the court would be whether the particular classification is "reasonable."70 But it is difficult to argue that the Constitution requires that a newspaper be granted immunity from jurisdiction when it sells its product in the state and that product causes injury to someone in the state, when at the same time the Constitution will allow the state to assert jurisdiction over a boiler manufacturer, whose product is eventually sold in the state, if one of its boilers injures a local citizen. ${ }^{71}$ Since fairness depends on treating those with contacts similar in amount and kind similarly, the inclusion of additional factors, such as the nature of the business entity, is likely to produce inequitable results in some cases. Moreover, such an approach would again ignore the interests of the individual in having a readily available forum in which to litigate his complaints, and of the state in protecting its citizens from attacks on their reputations. ${ }^{72}$

Furthermore, the distinction between advertising and circulation activities is particularly unsuited to the libel situation, for in libel cases it is through the process of circulation that the plaintiff is injured. ${ }^{3}$ Since circulation is the activity which actually causes the injury, it is difficult to see why the distribution activities of a newspaper should not be given the most weight in determining whether jurisdiction should be asserted, much less why they should be given less weight than other kinds of contacts. Moreover, the cases indicate that when contacts are slight, causation may be the determining factor. ${ }^{74}$ Normally,

general notions of the limits of a state's rightful sovereignty." Currie, The Growth of the Long Arm, 1963 U. ILL. L.F. 533, 535.

68 See note 56 supra.

69 See note 57 supra.

70 See, e.g., Morey v. Doud, 354 U.S. 457 (1957); Williamson v. Lee Optical Co., 348 U.S. 483 (1955); Railway Express Agency v. New York, 336 U.S. 106 (1949).

71 Gray v. American Radiator \& Standard Sanitary Corp., 22 Ill. 2d 432, 176 N.E.2d 761 (1961).

72 See Curtis Publishing Co. v. Birdsong, 360 F.2d 344, 346-47 (5th Cir. 1966).

73 Before the plaintiff can maintain a cause of action for libel, he must prove that the allegedly libelous article has been "published," i.e., shown to a third party. See Ostrowe v. Lee, 256 N.Y. 36,175 N.E. 505 (1931). In this context, circulation is simply a term used to describe the process of making numerous individual "publications." Once publication is established, the injury to the plaintiff's reputation is presumed if the article is libelous per se. New York Times Co. v. Sullivan, 273 Ala. 656, 675, 144 So. 2d 25, 39 (1962), rev'd on other grounds, 376 U.S. 254 (1964). If the statements would normally tend to injure the person libeled by them in his trade or business or to bring him into public contempt, then the statements constitute libel per se. Id. at 673,144 So. $2 \mathrm{~d}$ at 37 . Thus, for all practical purposes, circulation of the libelous article is the final step in the chain of causation for a libel action and is therefore a crucial factor in the action.

74 See International Shoe Co. v. Washington, 326 U.S. 310, 317 (1945); Bibie v. T.D. Publishing Co., 252 F. Supp. 185, 189 (N.D. Cal. 1966). 
for example, the presence of a newspaper's reporter within a state would not subject the paper to the jurisdiction of the state's courts, but if the reporter, while pursuing the business of the newspaper, struck a local citizen with his car, the newspaper would undoubtedly be subject to a personal injury suit in the state, ${ }^{75}$ unless the out-of-state motorist statute involved did not allow the court to assert its jurisdictional power to the constitutional limits. ${ }^{78}$ As in these automobile cases, the contact which causes the injury in libel-circulation activities-should be given the most weight in determining whether the contacts are sufficient.

Finally, because of the multitude of distinctions and factual problems the courts will have to face when applying the advertising-circulation distinction, the distinction may prove to be useless as a workable proposition. Some newspapers, for example, may carry many institutional advertisements which are clearly aimed at readers of the paper all over the country;77 other newspapers may not rely heavily on advertising revenue. If advertising activities are to be given additional weight in the jurisdictional formula because the newspaper depends on such activities for most of its revenue, then it would seem that the court should be required to single out those papers which do not depend so heavily upon advertising and emphasize the circulation activities of such newspapers when it applies the long arm statute. Yet, the court may not want to engage in such fact-finding at the jurisdictional level. Thus, the distinction between advertising and circulation activities does not appear to be a particularly helpful tool, even where libel is not involved.

In summary, it would appear that neither first amendment considerations nor due process requirements militate in favor of a higher jurisdictional threshold for foreign newspapers involved in libel actions. ${ }^{78}$ The dangers sought to be avoided by the Connor decision can probably be more equitably and efficiently avoided by compelling appellate courts to look more carefully at the damage awards in libel cases or to

75 See, e.g., Tanksley v. Dodge, 181 F.2d 925 (5th Cir. 1950); Herchelroth v. Mahar, 24 Wis. 2d 444, 129 N.W.2d 140 (1964); cf. Demn v. Royal Bros. Co., 111 Ga. App. 322, 141 S.E.2d 546 (1965). But see Clemens v. District Ct., 154 Colo. 176, 390 P.2d 83 (1964).

76 See, e.g., Cabe v. Edwards, 107 Ga. App. 551, 130 S.E.2d 803 (1963).

77 In 1961 institutional advertising accounted for $\$ 802,000,000$ out of a total of $\$ 3,600,000,000$ in advertising revenue for newspapers. Inrernational Typographical UnIoN, op. cit. supra note 33, at 29.

78 In a recent decision the Second Circuit rejected the first amendment argument of the Connor court and held newspapers subject to the same jurisdictional standards as other kinds of businesses. Buckley v. New York Post Corp., Civil No. 30757, 2d Cir., Jan. 10, 1967 (Friendly, J.). 
review more extensively the facts supporting the finding of malice required by Sullivan. ${ }^{79}$

79 Thus, the Connor court's holding that the evidence did not support the jury's finding of malice, $365 \mathrm{~F} .2 \mathrm{~d}$ at 572 , may point the way to a better solution of the newspaper libel problem than does its first amendment proposition. 